\title{
Structure-Based Design of a Cyclic Peptide Inhibitor of the SARS- CoV-2 Main Protease
}

\author{
Adam G. Kreutzer, ${ }^{a}$ Maj Krumberger, ${ }^{\text {a }}$ Chelsea Marie T. Parrocha, ${ }^{b}$ Michael A. Morris, ${ }^{a}$ \\ Gretchen Guaglianone, ${ }^{a}$ and James S. Nowick ${ }^{* a, b}$ \\ ${ }^{a}$ Department of Chemistry, University of California, Irvine \\ ${ }^{b}$ Department of Pharmaceutical Sciences, University of California, Irvine \\ Irvine, California 92697-2025, United States
}

\begin{abstract}
This paper presents the design and study of a first-in-class cyclic peptide inhibitor against the SARS-CoV-2 main protease $\left(\mathrm{M}^{\mathrm{pro}}\right)$. The cyclic peptide inhibitor is designed to mimic the conformation of a substrate at a $C$-terminal autolytic cleavage site of $\mathrm{M}^{\text {pro }}$. Synthesis and evaluation of a first-generation cyclic peptide inhibitor reveals that the inhibitor is active against $\mathrm{M}^{\mathrm{pro}}$ in vitro and is non-toxic toward human cells in culture. The initial hit described in this manuscript, UCI-1, lays the groundwork for the development of additional cyclic peptide inhibitors against $\mathrm{M}^{\mathrm{pro}}$ with improved activities.
\end{abstract}




\section{INTRODUCTION}

Antiviral drugs are desperately needed to help combat the COVID-19 pandemic caused by the Severe Acute Respiratory Syndrome coronavirus 2 (SARS-CoV-2), as well as epidemics caused by other coronaviruses in the future. ${ }^{1,2}$ Antiviral drugs that slow or halt viral replication can lead to a shortened time to recovery from COVID-19, offering the promise of improved mortality rates and alleviation of the tremendous strain experienced by hospitals during the COVID-19 pandemic. ${ }^{3}$

The main protease $\left(\mathrm{M}^{\mathrm{pro}}\right.$ or 3CL protease) is one of the best-characterized drug targets for coronaviruses. $^{4,5,6,7,8,9,10}$ The SARS-CoV-2 main protease is a member of a of class homologous cysteine proteases that are needed for viral replication in diseases such as Severe Acute Respiratory Syndrome (SARS) and Middle East Respiratory Syndrome (MERS). These viruses cleave the initially translated viral polyprotein into its component proteins. Cleavage generally occurs immediately after a Gln residue, and the Gln residue is typically preceded by a hydrophobic residue, most often Leu. The residue that follows the Gln is often a small amino acid such as Ser, Ala, or Asn. $\mathrm{M}^{\text {pro }}$ autolytically cleaves itself from the polyprotein. ${ }^{11}$ Inhibiting $\mathrm{M}^{\text {pro }}$ activity slows or halts viral replication, offering the promise of improved clinical outcomes for COVID-19 and other coronavirus diseases. Furthermore, there are no known human proteases with similar cleavage specificity to $\mathrm{M}^{\text {pro }}$, suggesting that it should be possible to develop inhibitors that target $\mathrm{M}^{\text {pro }}$ without off-target toxicity.

The SARS-CoV-2 $\mathrm{M}^{\text {pro }}$ amino acid sequence is $96 \%$ identical to the SARS-CoV $\mathrm{M}^{\text {pro }}$ amino sequence, and the three-dimensional structure of the SARS-CoV-2 $\mathrm{M}^{\text {pro }}$ is highly similar to the structure of the SARS-CoV $\mathrm{M}^{\text {pro }} \cdot{ }^{12}$ Peptide-based inhibitors previously developed to target the SARS-CoV $\mathrm{M}^{\text {pro }}$ have effectively been repurposed and modified to target the SARS-CoV-2 
$\mathrm{M}^{\text {pro }}$ - N3 from Jin et al., 13b from Zhang et al., and 11a and 11b from Dai et al. ${ }^{12,13,14}$ These inhibitors effectively block SARS-CoV-2 replication in cell-based studies, making them promising antiviral drug candidates. While the $\mathrm{M}^{\text {pro }}$ inhibitors $\mathrm{N} 3,13 \mathrm{~b}, 11 \mathrm{a}$, and $11 \mathrm{~b}$ have shown promise against inhibiting SARS-CoV-2 replication, additional $\mathrm{M}^{\text {pro }}$ inhibitors will most likely be needed for their improved properties or to be used in combination therapies. ${ }^{15}$

In this paper, we describe the design and preliminary evaluation of UCI-1 (University of California, Irvine Coronavirus Inhibitor-1), a first-in-class cyclic peptide that inhibits the SARSCoV-2 $\mathrm{M}^{\text {pro }}$ (Figure 1). UCI-1 is designed to mimic the conformation of a $C$-terminal autolytic cleavage site of the SARS-CoV $\mathrm{M}^{\text {pro }}$, a naturally occurring $\mathrm{M}^{\text {pro }}$ substrate. UCI-1 contains amino acid side chains from the $\mathrm{P} 2, \mathrm{P} 1, \mathrm{P} 1$ ', and $\mathrm{P} 2$ ' positions of the $\mathrm{M}^{\text {pro }}$ substrate that are designed to fill the S2, S1, S1', and S2' pockets of the $\mathrm{M}^{\text {pro }}$ active site (Figure 1A). In UCI-1, the carboxyterminus of the P2' residue is linked to the amino-terminus of the P2 residue with a [4-(2aminoethyl)phenyl]-acetic acid (AEPA) group, creating a cyclophane. The (2-aminoethyl)phenyl group of AEPA is designed to act as a surrogate for a phenylalanine side chain at position P3' and fill the S3' pocket. Evaluation of the first generation cyclic peptide inhibitor UCI-1 in an in vitro $\mathrm{M}^{\text {pro }}$ inhibition assay reveals that UCI-1 is active against SARS-CoV-2 $\mathrm{M}^{\text {pro }}$ at midmicromolar concentrations. LC/MS analysis indicates that UCI-1 resists cleavage by $\mathrm{M}^{\text {pro }}$, despite containing a scissile amide bond. Furthermore, UCI-1 is found to be non-toxic toward human embryonic kidney cells at concentrations that inhibit $\mathrm{M}^{\mathrm{pro}}$. The following details the design, synthesis, and preliminary evaluation of UCI-1. 


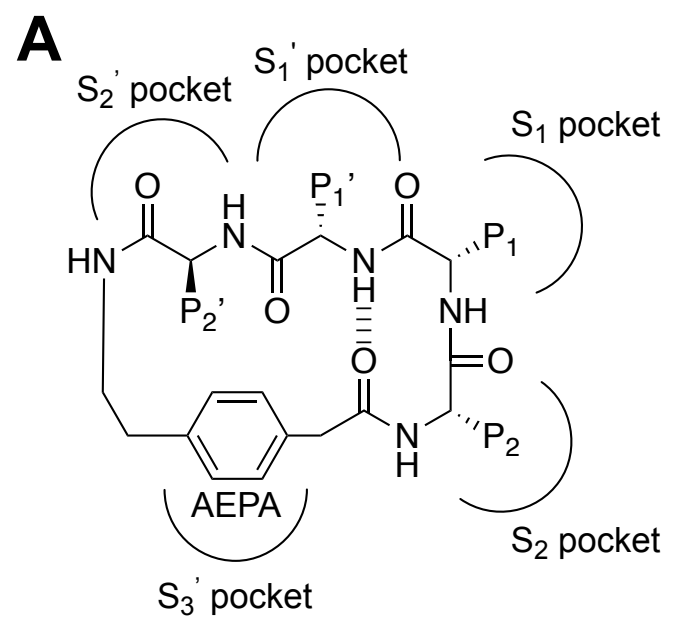

B

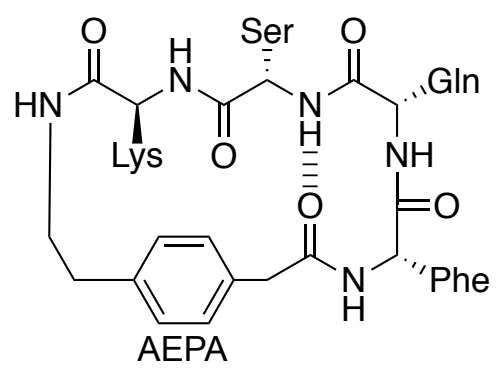

\section{$\mathrm{UCl}-1$}

Figure 1. (A) Chemical structure of a general cyclic peptide inhibitor illustrating the arrangement of the P2, P1, P1', and P2' positions and [4-(2-aminoethyl)phenyl]-acetic acid (AEPA) and the envisioned binding interactions with the S3, S2, S1, S1', and S2' pockets in the $\mathrm{M}^{\mathrm{pro}}$ active site. (B) Chemical structure of UCI-1.

\section{RESULTS AND DISCUSSION}

Design of the cyclic peptide inhibitor. We designed the cyclic peptide inhibitor based on the crystal structure of an inactive SARS-CoV $\mathrm{M}^{\text {pro }}(\mathrm{C} 145 \mathrm{~A})$ variant with a 10 amino-acid $C$ terminal extension corresponding to the $C$-terminal prosequence of $\mathrm{M}^{\text {pro }}$ (PDB 5B6O) (Figure 2). ${ }^{16}$ We term this $\mathrm{M}^{\text {pro }}$ variant " $\mathrm{M}^{\mathrm{pro}}{ }_{316 "}$. In the $\mathrm{M}^{\mathrm{pro}}{ }_{316}$ crystal structure, $C$-terminal residues 301-310 (SGVTFQGKFK) extend into and complex with the active site of another $\mathrm{M}_{316}^{\mathrm{pro}}$ molecule in an adjacent asymmetric unit (Figure 2 inset). This complex reveals how the P2-P1- 
bioRxiv preprint doi: https://doi.org/10.1101/2020.08.03.234872; this version posted August 5, 2020. The copyright holder for this preprint

(which was not certified by peer review) is the author/funder, who has granted bioRxiv a license to display the preprint in perpetuity. It is made available under aCC-BY 4.0 International license.

P1'-P2'-P3' positions (residues 305-309, FQGKF) of the $C$-terminal autolytic cleavage site fit into the active site of $\mathrm{M}^{\mathrm{pro}}{ }_{316}$. 


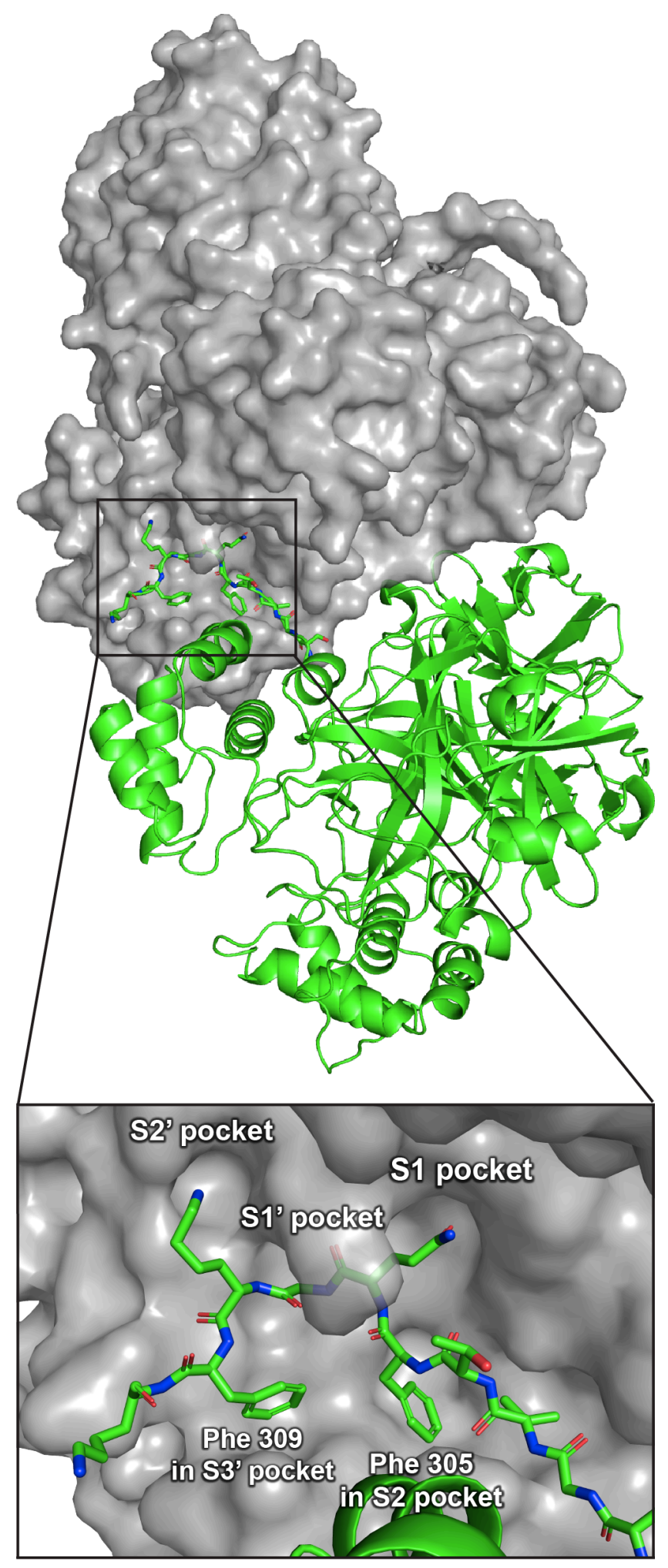

Figure 2. Crystal structure of $\mathrm{M}^{\text {pro }}{ }_{316}$ showing two $\mathrm{M}^{\text {pro }}{ }_{316}$ dimers in two adjacent asymmetric units (PDB 5B6O). One dimer is shown in grey surface view; the other dimer is shown in green cartoons. The inset shows a detailed view of $C$-terminal residues $301-310$ of the $C$-terminal autolytic cleavage site of one $\mathrm{M}_{316}^{\mathrm{pro}}$ molecule in the active site of another $\mathrm{M}^{\text {pro }}{ }_{316}$ molecule. 
The cyclic peptide inhibitor is designed to mimic the conformation that the P2-P1-P1'P2'-P3' residues adopt in the active site of $\mathrm{M}^{\mathrm{pro}}{ }_{316}$. In the active site of $\mathrm{M}^{\mathrm{pro}}{ }_{316}$, the P2-P1-P1'P2'-P3' residues adopt a "kinked" conformation in which the phenyl group of Phe309 at the P3' position points toward the backbone of Phe 305 at the $\mathrm{P} 2$ position (Figure 2 inset). To mimic this conformation, we envisioned linking the phenyl group of Phe309 to the backbone of Phe305 to create a macrocycle. To realize this design, we used the molecular visualization software PyMOL (version 2.2.2, Schrödinger) to build a model of the envisioned cyclic peptide by modifying Phe305 and Phe309 in the active site of $\mathrm{M}_{316}^{\mathrm{pro}}$ (Figure 3). In PyMOL, we deleted residues 301-304 to expose the amino group on Phe305; we also deleted residue 308 and the carbonyl of Phe309. We then connected the para position of Phe309 to the amino group of Phe305 with a $\mathrm{CH}_{2} \mathrm{CO}$ group to create a macrocycle. The newly created amino acid derived from Phe309 thus constitutes the amino acid AEPA.

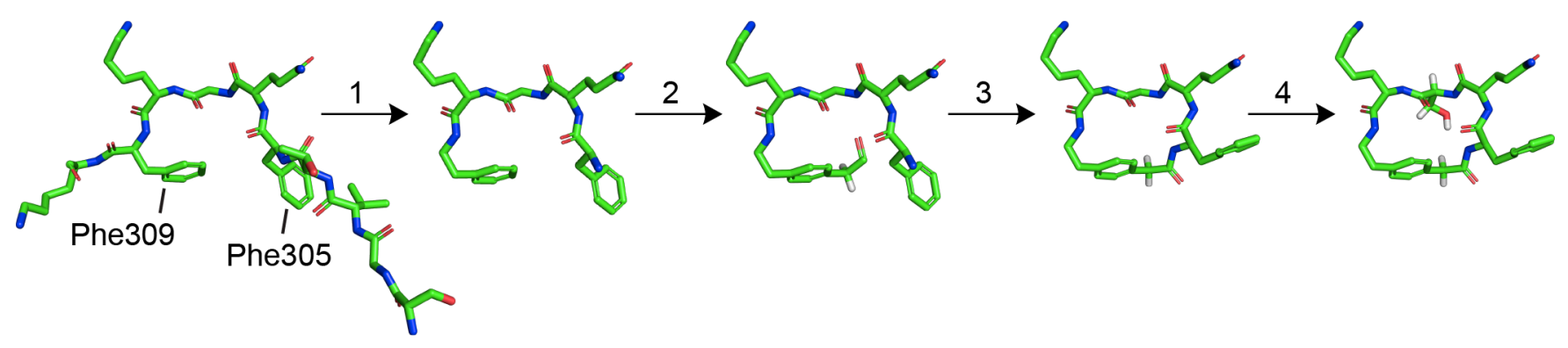

Figure 3. Design process for creating the cyclic peptide inhibitor UCI-1 from the $C$-terminal autolytic cleavage site that extends into the active site of the enzyme: (1) Delete residues 301304 and 308 as well as the carbonyl of Phe309. (2) Build a $\mathrm{CH}_{2} \mathrm{CO}$ group on the para position of the phenyl group on Phe309. (3) Create a bond between the carbonyl carbon of the newly created $\mathrm{CH}_{2} \mathrm{CO}$ group on Phe309 and the amino group of Phe305, and then invert the stereochemistry of Phe305. (4) Mutate Gly307 to serine.

We recognized that upon linking Phe309 and Phe305 as described above, Phe305 and Gln306 were poised to form a $\beta$-turn in which the carbonyl of AEPA hydrogen bonds with the 
amino group of Gly307. We envision that $\beta$-turn formation in the cyclic peptide inhibitor will promote rigidity of the cyclic scaffold. To introduce additional conformational rigidity to the macrocycle, we also mutated Gly307 to serine, which is the most common residue at the P1' position among the 11 known SARS-CoV-2 $\mathrm{M}^{\text {pro }}$ cleavage sites. The resulting cyclic peptide inhibitor UCI-1 was then synthesized and further studied as described below.

Synthesis of UCI-1. We synthesized UCI-1 by Fmoc-based solid-phase peptide synthesis of the protected linear peptide $\mathrm{H}_{2} \mathrm{~N}-\mathrm{FQSK}-\mathrm{AEPA}-\mathrm{COOH}$ on 2-chlorotrityl chloride resin followed by cleavage of the linear protected peptide from the resin and subsequent solutionphase macrocyclization and global deprotection (Scheme 1). UCI-1 was purified using reversephase HPLC. The synthesis and purification proceeded smoothly on a $0.1 \mathrm{mmol}$ scale and yielded $22 \mathrm{mg}$ of purified UCI-1 as the TFA salt. Detailed procedures for synthesis of UCI-1 are given in the Materials and Methods section. 
Scheme 1. Synthesis of UCI-1.
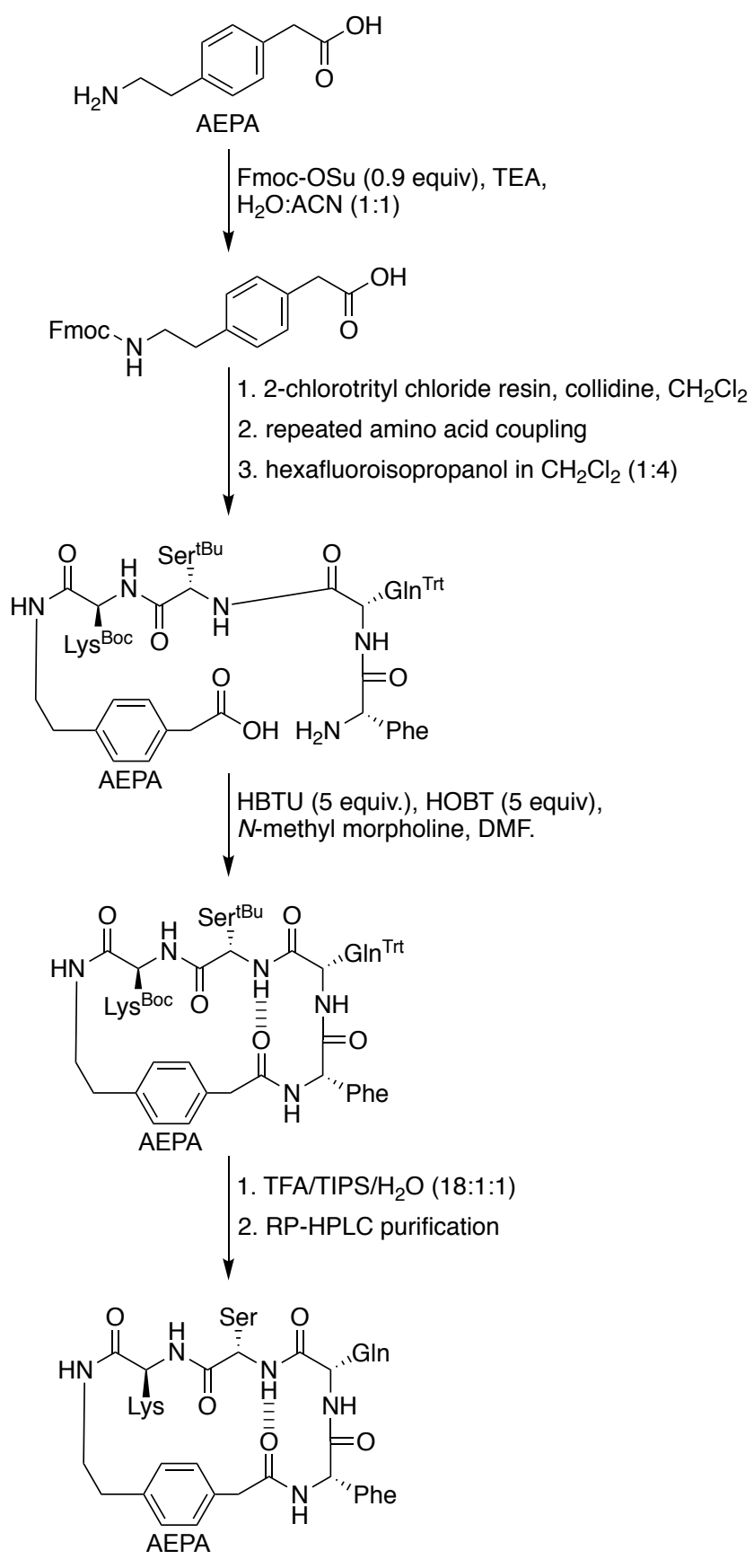

UCl-1 (TFA salt)

Enzyme inhibition assay. To evaluate the inhibitory properties of UCI-1 against $\mathrm{M}^{\text {pro }}$, we used an established fluorescence-based $\mathrm{M}^{\text {pro }}$ inhibition assay kit from BPS Bioscience. The kit 
includes purified SARS-CoV-2 $\mathrm{M}^{\text {pro }}$ as a fusion protein with maltose binding protein (MBP$\mathrm{M}^{\mathrm{pro}}$ ), the fluorogenic $\mathrm{M}^{\mathrm{pro}}$ substrate Dabcyl-KTSAVLQSGFRKM-E(Edans)- $\mathrm{NH}_{2}$, and assay buffer. For the inhibition assay, we pre-incubated $M B P-M^{\text {pro }}$ with varying concentrations of UCI-1 (32-512 $\mu \mathrm{M})$ or with varying concentrations of the acyclic variant of UCI-1, "peptide-1a" $(32-256 \mu \mathrm{M})$, in assay buffer for $30 \mathrm{~min}$. We then added the fluorogenic $\mathrm{M}^{\text {pro }}$ substrate and monitored MBP-M ${ }^{\text {pro }}$ activity in a continuous kinetic assay using wavelengths of $360 \mathrm{~nm}$ and $460 \mathrm{~nm}$ for excitation and emission. In each well, the concentration of MBP-M ${ }^{\text {pro }}$ was $0.2 \mu \mathrm{M}$ and the concentration of the fluorogenic substrate was $50 \mu \mathrm{M}$. Figure S1 shows the results of the results of the continuous kinetic assay of UCI-1.

Initial rates for MBP-M $\mathrm{M}^{\text {pro }}$ activity in the presence or absence of UCI-1 or peptide-1a were obtained by fitting the linear portions of the curves from the continuous kinetic assay to a straight line. UCI-1 is active against $\mathrm{MBP}-\mathrm{M}^{\mathrm{pro}}$ with an $\mathrm{IC}_{50}$ value of $\sim 150 \mu \mathrm{M}$ (Figure $4 \mathrm{~A}$ ). In contrast, the linear control peptide-1a shows little or no inhibition at concentrations at or below $256 \mu \mathrm{M}$ (Figure 4B). There appears to be a slight reduction in rate of cleavage of the fluorogenic substrate upon addition of $256 \mu \mathrm{M}$ peptide-1a. This reduction in rate may reflect either slight inhibition of $\mathrm{MBP}-\mathrm{M}^{\mathrm{pro}}$ or that the linear peptide acts as a competitive substrate at high concentrations. These findings indicate that the cyclic structure of UCI-1 is critical for its activity.

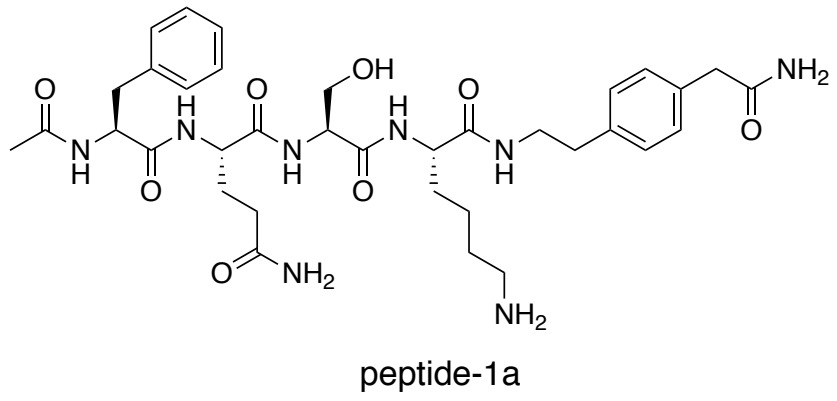



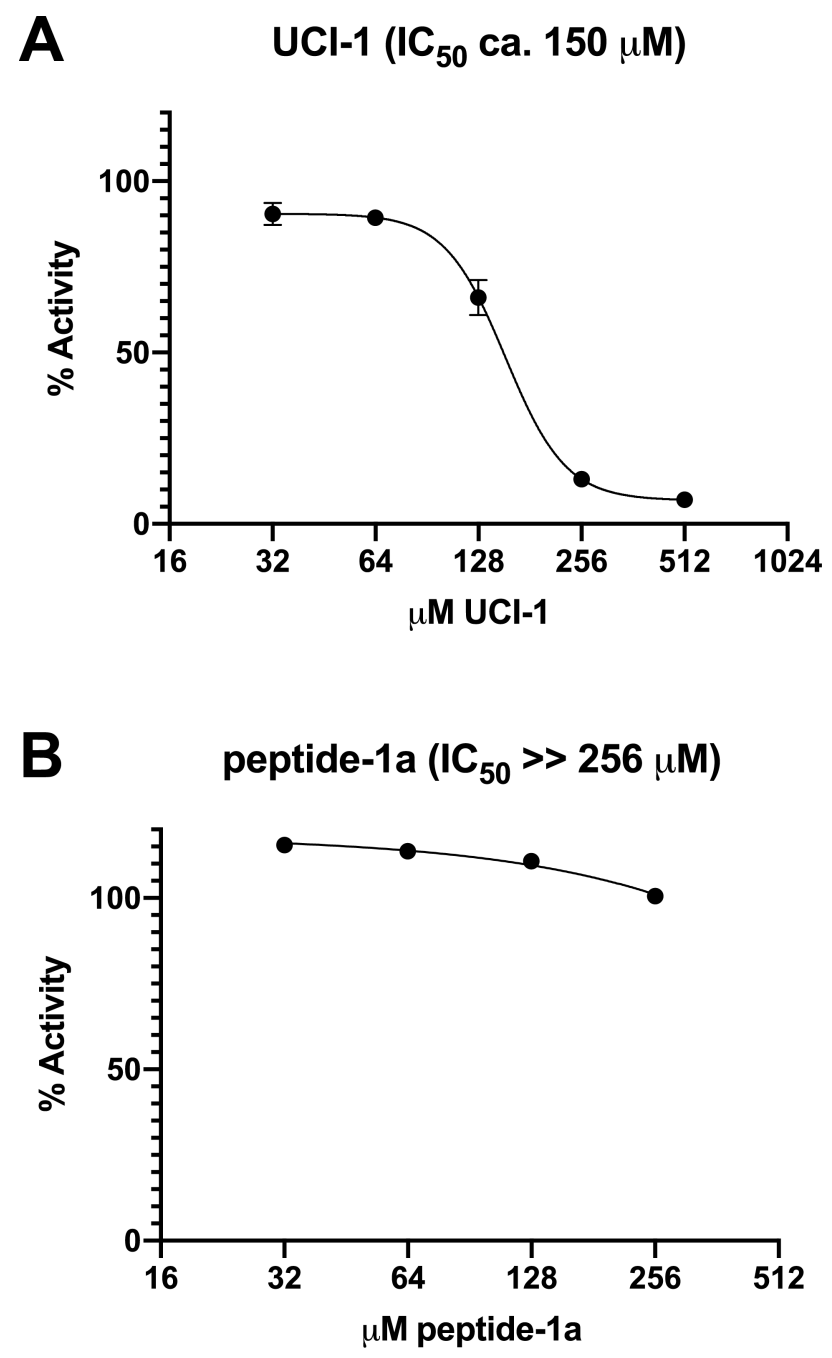

Figure 4. Enzyme inhibition assays. The activity of $M B P-M^{\text {pro }}$ was measured in the presence of increasing concentrations of UCI-1 (A) or lin-UCI-1 (B). Dose response curves for $\mathrm{IC}_{50}$ values were determined by non-linear regression. All data are shown as mean \pm s.d., $n=3$ replicates.

Assessment of cleavage of UCI-1 by $M^{\text {pro }}$. The amide bond between residues at positions P1 and P1' of UCI-1 has the potential to be cleaved by $\mathrm{M}^{\text {pro }}$ because residues at these positions correspond to the cleavage site of $\mathrm{M}^{\text {pro }}$ substrates. To determine whether $\mathrm{M}^{\text {pro }}$ cleaves UCI-1, we used LC/MS to analyze UCI-1 in the well solution from the 96-well plate of the enzyme inhibition assay after 24 hours. To aide in LC/MS identification of the cleavage product of UCI1, we synthesized the authentic UCI-1 $\mathrm{M}^{\text {pro }}$ cleavage product "peptide-1b" and spiked the well solution with peptide-1b. 
UCI-1 does not appear to be cleaved by $\mathrm{M}^{\text {pro }}$ (Figure 5). LC/MS analysis of the enzyme inhibition assay well solution with $16 \mu \mathrm{M}$ UCI-1 spiked with $0.1 \mu \mathrm{M}$ peptide-1b shows a small peak at 2.09 minutes that corresponds to peptide-1b (Figure 5B). The peak at 2.09 minutes is absent in the LC/MS trace acquired before spiking the well solution with peptide-1b (Figure 5A), indicating that there is not appreciable cleavage of UCI-1 by $\mathrm{M}^{\text {pro }}$. The ion current at 2.09 minutes in the LC/MS trace acquired before spiking with peptide-1b shows no evidence of the UCI-1 cleavage product (Figure 5C), whereas the ion current at 2.09 minutes in the LC/MS trace acquired after spiking with peptide-1b shows the mass of peptide-1b (Figure 5D), providing additional evidence that UCI- 1 resists cleavage by $\mathrm{M}^{\mathrm{pro}}$. These findings confirm that UCI- 1 acts as an inhibitor and not a competitive substrate. The resistance of UCI-1 to cleavage by $\mathrm{M}^{\text {pro }}$ is consistent with the observations by others that cyclic peptides often resist proteolytic cleavage. $^{17,18,19,20,21,22}$<smiles>NCCCC[C@H](NC(=O)C(N)CO)C(=O)NCCc1ccc(CC(=O)N[C@@H](Cc2ccccc2)C(=O)N[C@@H](CCC(N)=O)C(=O)O)cc1</smiles> 

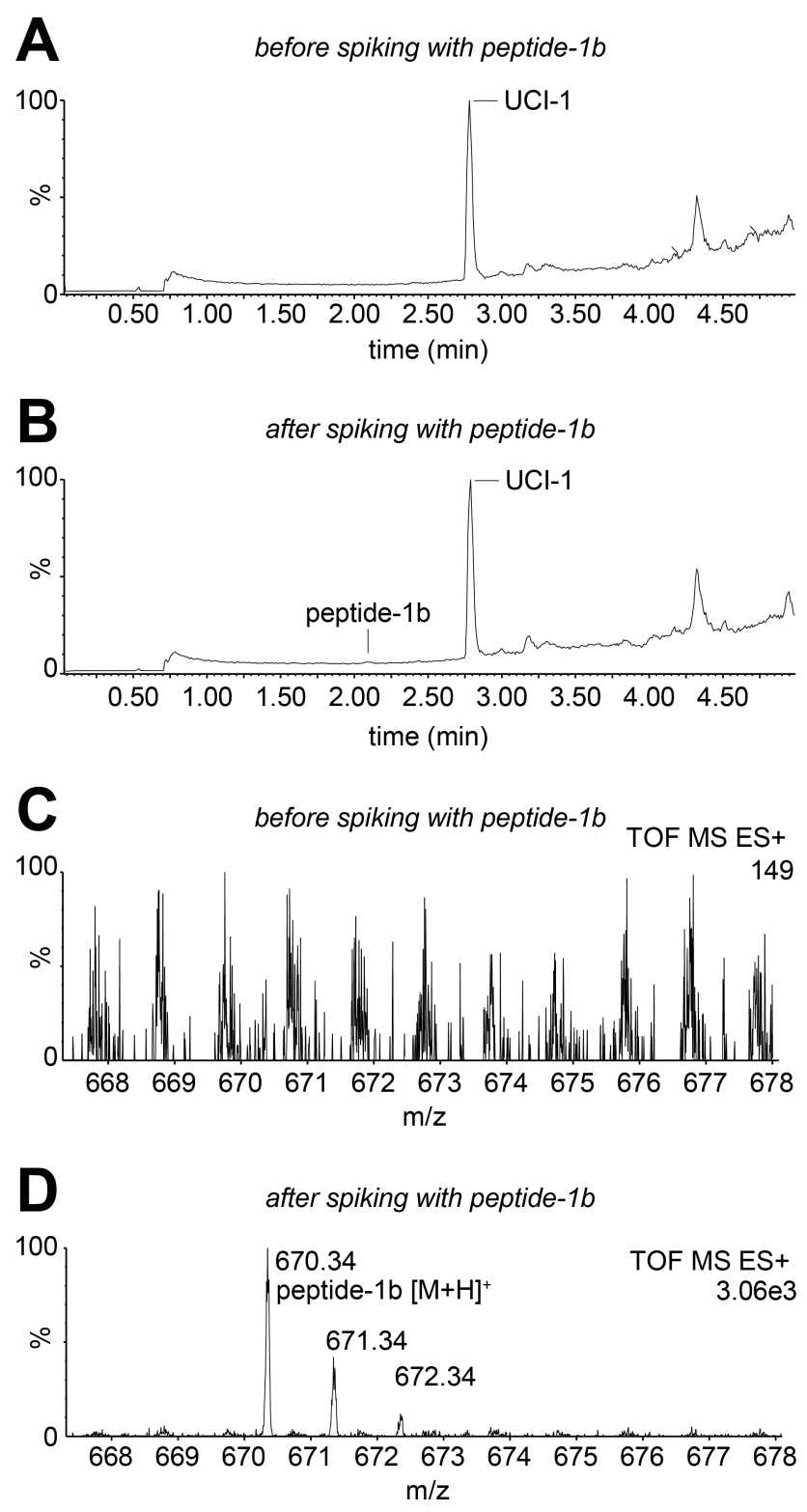

Figure 5. Assessment of cleavage of UCI-1 by $\mathrm{M}^{\text {pro }}$ using LC/MS. (A) LC/MS total ion current spectrum of well solution from $\mathrm{M}^{\text {pro }}$ inhibition assay with $16 \mu \mathrm{M}$ UCI-1. (B) LC/MS total ion current spectrum of well solution from $\mathrm{M}^{\text {pro }}$ inhibition assay with $16 \mu \mathrm{M}$ UCI-1 spiked with 0.1 $\mu \mathrm{M}$ peptide-1b. (C) Ion current for peptide-1b (2.09 $\mathrm{min})$ in LC/MS spectrum of well solution from $\mathrm{M}^{\text {pro }}$ inhibition assay with $16 \mu \mathrm{M}$ UCI-1. (D) Ion current for peptide-1b (2.09 $\left.\mathrm{min}\right)$ in LC/MS spectrum of well solution from $\mathrm{M}^{\text {pro }}$ inhibition assay with $16 \mu \mathrm{M}$ UCI-1 spiked with 0.1 $\mu \mathrm{M}$ peptide- $1 \mathrm{~b}$.

Cytotoxicity of UCI-1. To evaluate whether UCI-1 is cytotoxic, we exposed human embryonic kidney (HEK-293) cells to varying concentrations of UCI-1 (0-256 $\mu \mathrm{M})$ for 72 hours, 
and then assessed cell death using a lactase dehydrogenase (LDH) assay. At the highest concentration evaluated $(256 \mu \mathrm{M})$, UCI-1 elicits little to no LDH release from HEK-293 cells, indicating that UCI-1 is not cytotoxic at concentrations up to $256 \mu \mathrm{M}$ (Figure 6).

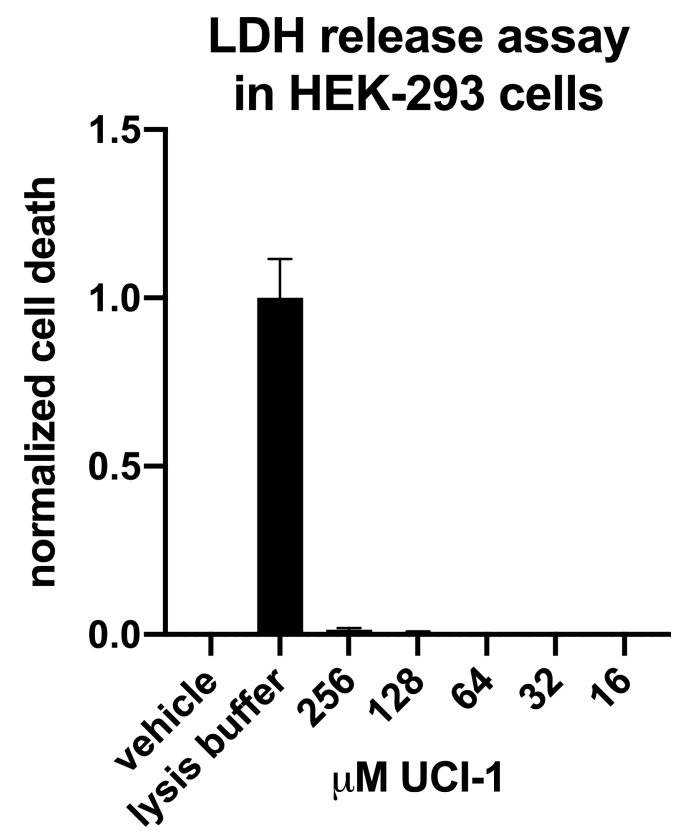

Figure 6. LDH release assay of UCI-1 in HEK-293 cells. All data are shown as mean \pm s.d., $n=$ 5 replicates. Deionized water (vehicle) was used as a negative control.

Conformational analysis and docking of UCI-1. To better understand the threedimensional structure of UCI-1 and how it interacts with the active site of the SARS-CoV-2 $\mathrm{M}^{\text {pro }}$, we performed conformational analysis and docking studies. Conformational searching of UCI-1 (MacroModel with the MMFFs force field and GB/SA water) revealed that UCI-1 adopts a global minimum energy conformation that resembles the kinked conformation that residues 305-309 adopt in the active site of $\mathrm{M}^{\mathrm{pro}}{ }_{316}$ (Figures 2 and 7A). In the global minimum energy conformation, the AEPA residue acts as a rigid spacer, with the Phe, Gln, Ser, and Lys forming a bridge. As we had envisioned, the Phe and Gln residues adopt a $\beta$-turn conformation, with Phe at the $\mathrm{i}+1$ position and Gln at the $\mathrm{i}+2$ position. The Phe side chain is well situated to fit in the S2 
pocket, and the Gln side chain is well situated to fit in the S1 pocket. The Ser, Lys, and AEPA residues, in turn, are poised to occupy the S1', S2', and S3' pockets. The macrocyclic scaffold of the cyclic peptide inhibitor appears to be particularly rigid. In the conformational search, the peptide backbones of most of the conformers adopt the conformation described above, differing only in side chain geometry and the type of $\beta$-turn formed by Phe305 and Gln306 (Figure 7B). Docking of the lowest energy conformer of UCI-1 with the SARS-CoV-2 M pro $^{\text {PDB } 6 Y B 7)}$ using Autodock Vina reveals that the inhibitor binds the active site of $\mathrm{M}^{\text {pro }}$ in the envisioned manner (Figure 7C). ${ }^{23}$ 

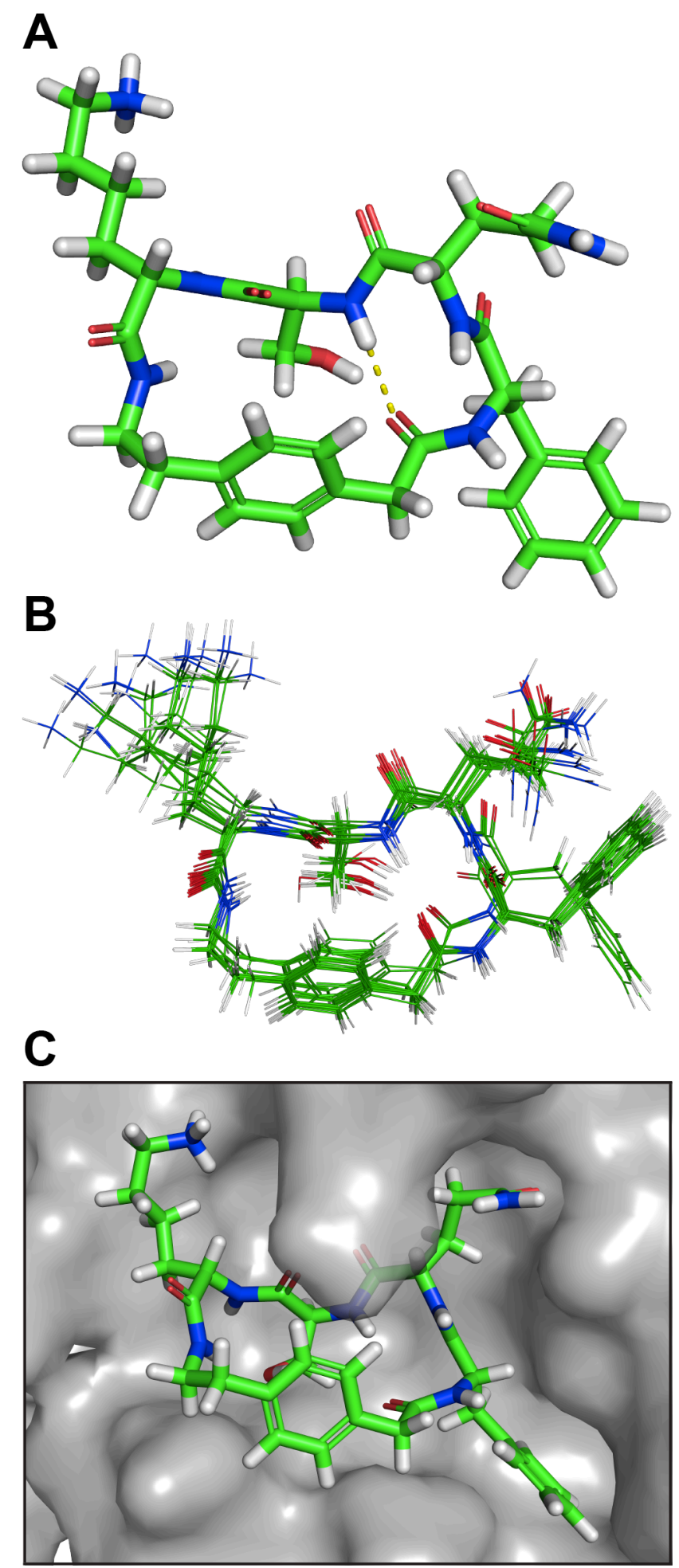

Figure 7. (A) Lowest energy conformer of UCI-1. (B) Superposition of the 20 lowest energy conformers from conformational searching. The difference in energy between the lowest and highest energy conformers among these 20 is $7.0 \mathrm{~kJ} / \mathrm{mol}$. (C) UCI-1 in complex with the SARSCoV-2 $\mathrm{M}^{\text {pro }}$ active site generated in Autodock Vina. The SARS-CoV-2 $\mathrm{M}^{\text {pro }}$ crystal structure with PDB accession number 6YB7 was used in the docking study. 


\section{CONCLUSIONS}

The design and preliminary evaluation of UCI-1 demonstrates that cyclic peptides that mimic the conformation of linear peptide substrates of $\mathrm{M}^{\text {pro }}$ can be developed as inhibitors against $\mathrm{M}^{\text {pro }}$. Almost all of the $\mathrm{M}^{\text {pro }}$ inhibitors that have been reported are linear peptides that contain a "warhead" that forms a covalent bond with the active cysteine of $\mathrm{M}^{\text {pro }}$. While the activity of UCI-1 is modest compared to other known $\mathrm{M}^{\text {pro }}$ inhibitors, the design and preliminary evaluation of UCI-1 lays the groundwork for developing additional cyclic peptide inhibitor analogs of UCI-1 with improved activity against $\mathrm{M}^{\mathrm{pro}}$. Design and development of next generation UCI-1 analogs will likely produce better inhibitors. Due to the urgency of COVID-19, we elected to share our initial hit, UCI-1, in this preprint. We hope that doing so will encourage others to also begin thinking about cyclic peptide inhibitors as promising drug candidates. We are currently pursuing next generation analogs of UCI-1 predicted to exhibit enhanced activity against $\mathrm{M}^{\text {pro }}$, and will report our findings from these pursuits in due course.

\section{MATERIALS AND METHODS}

Synthesis of 2-(4-(2-((((9H-fluoren-9-yl)methoxy)carbonyl)amino)ethyl)phenyl)acetic acid (Fmoc-AEPA). A $50 \mathrm{~mL}$ round-bottom flask equipped with a magnetic stirring bar was charged with $100 \mathrm{mg}$ (0.55 mmol, 1 equiv) of 2-(4-(2-aminoethyl)phenyl)acetic acid dissolved in $10 \mathrm{~mL} \mathrm{H} \mathrm{H}_{2} \mathrm{O} .0 .156 \mathrm{~mL}$ (1.10 mmol, 2 equiv) of $\mathrm{Et}_{3} \mathrm{~N}$ was added. $160 \mathrm{mg}$ of Fmoc-OSu (0.50 mmol, 0.9 equiv) was dissolved in $10 \mathrm{~mL} \mathrm{CH}_{3} \mathrm{CN}$ and added to the reaction mixture. The reaction was run for 2 hours at room temperature. While it was running, the reaction was monitored by TLC (3:1 EtOAc/hexanes $\left.+10 \% \mathrm{MeOH}, \mathrm{R}_{\mathrm{f}}=0.44\right)$ to determine the consumption of starting material $\left(\mathrm{R}_{\mathrm{f}}=0.77\right)$ and an appearance of fulvene $\left(\mathrm{R}_{\mathrm{f}}=0.81\right) .10 \mathrm{~mL}$ of EtOAc was 
then added to the reaction mixture and the organic layer was removed. The aqueous layer was acidified with $30 \mathrm{~mL} 1 \mathrm{M} \mathrm{HCl}$, and then $10 \mathrm{~mL}$ of EtOAc was added. The organic layer was washed with water and brine, dried over $\mathrm{MgSO}_{4}$, and solvent was evaporated in vacuo to afford a white powder $(70 \%, 0.140 \mathrm{~g})$. The Fmoc-AEPA was used in solid-phase peptide synthesis without further purification. The product contains a minor contaminant $(<10 \%)$ of FmocAEPA-AEPA-OH, as detected by ${ }^{1} \mathrm{H}$ NMR spectroscopy. HRMS (ESI-TOF) $m / z$ : $[\mathrm{M}+\mathrm{Na}]^{+}$calcd for $\mathrm{C}_{25} \mathrm{H}_{23} \mathrm{NO}_{4} 424.1525$ found 424.1507 .

Synthesis of UCI-1. 2-Chlorotrityl chloride resin (200 mg, $1.6 \mathrm{mmol} / \mathrm{g})$ was added to a Bio-Rad Poly-Prep chromatography column $(10 \mathrm{~mL})$. The resin was suspended in dry $\mathrm{CH}_{2} \mathrm{Cl}_{2}$ $(10 \mathrm{~mL})$ and allowed to swell for $30 \mathrm{~min}$. The solution was drained from the resin and a solution of Fmoc-AEPA-OH (0.50 equiv, $64 \mathrm{mg}, 0.16 \mathrm{mmol})$ in $6 \%(\mathrm{v} / \mathrm{v})$ 2,4,6-collidine in dry $\mathrm{CH}_{2} \mathrm{Cl}_{2}(8$ $\mathrm{mL}$ ) was added immediately and the suspension was gently agitated for $12 \mathrm{~h}$. The solution was then drained and a mixture of $\mathrm{CH}_{2} \mathrm{Cl}_{2} / \mathrm{MeOH} / N, N$-diisopropylethylamine (DIPEA) $(17: 2: 1,10$ $\mathrm{mL}$ ) was added immediately. The mixture was gently agitated for $1 \mathrm{~h}$ to cap the unreacted 2chlorotrityl chloride resin sites. The resin was then washed with dry $\mathrm{CH}_{2} \mathrm{Cl}_{2}(2 \mathrm{x})$ and dried by passing nitrogen through the vessel. This procedure yielded $0.26 \mathrm{mmol} / \mathrm{g}$ of loaded resin.

The Fmoc-AEPA-2-chlorotrityl resin was transferred to a peptide synthesis coupling vessel and subjected to cycles of peptide coupling with Fmoc-protected amino acid building blocks. The linear peptide was synthesized from the $C$-terminus to the $N$-terminus. Each coupling cycle consisted of i. Fmoc-deprotection with $20 \%(\mathrm{v} / \mathrm{v})$ piperidine in DMF for 5 min (2x), ii. washing with DMF (3x), iii. coupling of the amino acid (5 equiv) in the presence of HCTU (4.5 equiv) and 20\% (v/v) $N$-methylmorpholine (2,4,6-collidine) in DMF for 10-20 min. iv. washing with DMF (3x). After coupling of the last amino acid, the terminal Fmoc group was 
removed with 20\% (v/v) piperidine in DMF. The resin was transferred from the coupling vessel to a Bio-Rad Poly-Prep chromatography column.

The linear peptide was cleaved from the resin by agitating the resin for $1 \mathrm{~h}$ with a solution of 1,1,1,3,3,3-hexafluoroisopropanol (HFIP) in $\mathrm{CH}_{2} \mathrm{Cl}_{2}(1: 4,7 \mathrm{~mL}){ }^{24}$ The suspension was filtered and the filtrate was collected in a $250-\mathrm{mL}$ round-bottomed flask. The resin was washed with additional HFIP in $\mathrm{CH}_{2} \mathrm{Cl}_{2}(1: 4,7 \mathrm{~mL})$ and then with $\mathrm{CH}_{2} \mathrm{Cl}_{2}(2 \times 10 \mathrm{~mL})$. The combined filtrates were concentrated by rotary evaporation to give a white solid. The white solid was further dried by vacuum pump to afford the crude protected linear peptide, which was cyclized without further purification.

The crude protected linear peptide was dissolved in dry DMF (150 mL). HOBt (5 equiv) and HBTU (5 equiv) were added to the solution. NMM (12 equiv) was added to the solution and the mixture was stirred under nitrogen for $24 \mathrm{~h}$. The mixture was then concentrated under reduced pressure to afford the crude protected cyclic peptide.

The protected cyclic peptide was dissolved in TFA/triisopropylsilane (TIPS) $/ \mathrm{H}_{2} \mathrm{O}$ $(18: 1: 1,20 \mathrm{~mL})$ in a $250-\mathrm{mL}$ round-bottomed flask equipped with a nitrogen-inlet adaptor. The solution was stirred for $1.5 \mathrm{~h}$. The reaction mixture was then concentrated by rotary evaporation under reduced pressure to afford the crude cyclic peptide as a thin yellow film on the side of the round-bottomed flask. The crude cyclic peptide was immediately subjected to purification by reverse-phase HPLC (RP-HPLC).

The peptide was dissolved in $\mathrm{H}_{2} \mathrm{O}$ and acetonitrile $(7: 3,10 \mathrm{~mL})$, and the solution was filtered through a $0.2 \mu \mathrm{m}$ syringe filter and purified by RP-HPLC (gradient elution with 10-30\% $\mathrm{CH}_{3} \mathrm{CN}$ over $50 \mathrm{~min}$ ). Pure fractions were concentrated by rotary evaporation and lyophilized. The synthesis of UCI-1 yielded $22 \mathrm{mg}$ of the peptide as the TFA salt. 
Synthesis of peptide-1a. Rink amide AM resin $(300 \mathrm{mg}, 0.68 \mathrm{mmol} / \mathrm{g})$ was added to a peptide synthesis coupling vessel. The resin was suspended in dry DMF (10 mL) and allowed to swell for 30 min. The solution was drained from the resin and the Fmoc group was removed with $20 \%(\mathrm{v} / \mathrm{v})$ piperidine in DMF for $20 \mathrm{~min}$. The solution was drained and washed with DMF (5x). Fmoc-AEPA-OH ( 0.50 equiv, $40.8 \mathrm{mg}, 0.102 \mathrm{mmol})$, HATU (0.5 equiv), and HOAt ( 0.5 equiv) in $20 \%(\mathrm{v} / \mathrm{v}) 2,4,6$-collidine in dry DMF $(8 \mathrm{~mL})$ was then added to the resin mixed for $12 \mathrm{~h}$. The solution was then drained, washed with $\operatorname{DMF}(3 \mathrm{x})$ and a mixture of acetic anhydride/pyridine $(3: 2,10 \mathrm{~mL})$ was added. The resin was mixed for $15 \mathrm{~min}$ to cap the unreacted resin sites. The resin was then washed with DMF (3x). This procedure yielded $0.17 \mathrm{mmol} / \mathrm{g}$ of loaded resin.

The Fmoc-AEPA-Rink amide AM resin was subjected to cycles of peptide coupling with Fmoc-protected amino acid building blocks as described above, ending with cleavage of the terminal Fmoc. The resin was then washed with $\mathrm{CH}_{2} \mathrm{Cl}_{2}(3 \mathrm{x})$ and then dried by pushing $\mathrm{N}_{2}$ gas through the Poly-Prep column. The peptide was cleaved from the resin and globally deprotected by mixing the dried resin with TFA/triisopropylsilane (TIPS)/ $\mathrm{H}_{2} \mathrm{O}(18: 1: 1,10 \mathrm{~mL})$ and gently rocking for 2.5 hours. The peptide was drained into a glass beaker, precipitated in cold ether, and subjected to purification by RP-HPLC as described above. The synthesis of peptide-1a yielded $17 \mathrm{mg}$ of the peptide as the TFA salt.

Synthesis of peptide-1b. 2-Chlorotrityl chloride resin (300 mg, $1.6 \mathrm{mmol} / \mathrm{g}$ ) was added to a Bio-Rad Poly-Prep chromatography column $(10 \mathrm{~mL})$. The resin was suspended in dry $\mathrm{CH}_{2} \mathrm{Cl}_{2}$ $(10 \mathrm{~mL})$ and allowed to swell for $30 \mathrm{~min}$. The solution was drained from the resin and a solution of Fmoc-Gln(Trt)-OH (0.50 equiv, $146.57 \mathrm{mg}, 0.24 \mathrm{mmol})$ in 6\% (v/v) 2,4,6-collidine in dry $\mathrm{CH}_{2} \mathrm{Cl}_{2}(8 \mathrm{~mL})$ was added immediately and the suspension was gently agitated for $12 \mathrm{~h}$. The solution was then drained and a mixture of $\mathrm{CH}_{2} \mathrm{Cl}_{2} / \mathrm{MeOH} / N, N$-diisopropylethylamine (DIPEA) 
$(17: 2: 1,10 \mathrm{~mL})$ was added immediately. The mixture was gently agitated for $1 \mathrm{~h}$ to cap the unreacted 2-chlorotrityl chloride resin sites. The resin was then washed with dry $\mathrm{CH}_{2} \mathrm{Cl}_{2}(2 \mathrm{x})$ and dried by passing nitrogen through the vessel. This procedure yielded $0.36 \mathrm{mmol} / \mathrm{g}$ of loaded resin.

The Fmoc-Gln(Trt)- 2-chlorotrityl resin was subjected to cycles of peptide coupling with Fmoc-protected amino acid building blocks as described above, ending with cleavage of the terminal Fmoc. The resin was then washed with $\mathrm{CH}_{2} \mathrm{Cl}_{2}(3 \mathrm{x})$ and then dried by pushing $\mathrm{N}_{2}$ gas through the Poly-Prep column. The peptide was cleaved from the resin and globally deprotected by mixing the dried resin with TFA/triisopropylsilane (TIPS)/ $\mathrm{H}_{2} \mathrm{O}(18: 1: 1,10 \mathrm{~mL})$ and gently rocking for 2.5 hours. The peptide was drained into a glass beaker, precipitated in cold ether, and subjected to purification by RP-HPLC as described above. The synthesis of peptide-1b yielded $13 \mathrm{mg}$ of the peptide as the TFA salt.

Enzyme inhibition assay. A proprietary buffer containing detergent from BPS Bioscience was used for the inhibition assays. The substrate with the cleavage sites of $\mathrm{M}^{\text {pro }}$ (indicated by the arrow, $\downarrow$ ), Dabcyl-KTSAVLQ $\downarrow$ SGFRKM-E(Edans)- $\mathrm{NH}_{2}$ and (BPS Bioscience), was used in the fluorescence resonance energy transfer (FRET)-based continuous kinetic assay, using a backwalled 96-well plate. The dequenching of the Edans fluorescence due to the cleavage of the substrate by MBP-M ${ }^{\text {pro }}$ was monitored at $460 \mathrm{~nm}$ with excitation at $360 \mathrm{~nm}$, using a Varioskan LUX fluorescence spectrophotometer (Thermo Fisher) using the top-read mode. Stock solutions $(10 \mathrm{mg} / \mathrm{mL})$ of UCI-1 and peptide-1a were prepared gravimetrically by dissolving the peptides in deionized $\mathrm{H}_{2} \mathrm{O}$. For the determination of the $\mathrm{IC}_{50}, 0.2 \mu \mathrm{M}$ SARS-CoV-2 MBP-M ${ }^{\text {pro }}$ was incubated with UCI-1 or peptide-1a at various concentrations (32-512 $\mu \mathrm{M}$ for UCI-1 and 32-256 $\mu \mathrm{M}$ peptide-1a) in assay buffer at room temperature for $30 \mathrm{~min}$. Afterward, the reaction was 
initiated by adding the FRET peptide substrate at a $50 \mu \mathrm{M}$ final concentration (final volume: 50 $\mu \mathrm{L}$ ). The $\mathrm{IC}_{50}$ value for UCI-1 was determined using the GraphPad Prism 8.4.3 software (GraphPad) by plotting the initial rates. Measurements of enzymatic activity were performed in triplicate and are presented as the mean \pm standard deviations (s.d.).

$L C / M S$. LC/MS analysis of the pooled $16 \mu \mathrm{M}$ UCI-1 well solutions from the enzyme inhibition assay was performed on a Waters Xevo Qtof G2XS equipped with a C4 column. For both LC/MS traces, $10 \mu \mathrm{L}$ of the well solution (diluted 1:100 in deionized $\mathrm{H}_{2} \mathrm{O}$ ) was injected on the column. For the spiking experiment, a $10 \mathrm{mg} / \mathrm{mL}$ stock solution of peptide-1b was prepared gravimetrically in deionized $\mathrm{H}_{2} \mathrm{O}$, and an aliquot of the stock solution was diluted in deionized $\mathrm{H}_{2} \mathrm{O}$ to create a $10 \mu \mathrm{M}$ working solution. A $1-\mu \mathrm{L}$ aliquot of the $10 \mu \mathrm{M}$ working solution of peptide- $1 \mathrm{~b}$ was added to $100 \mu \mathrm{L}$ of the well solution to achieve a final peptide- $1 \mathrm{~b}$ concentration of $0.1 \mu \mathrm{M}$.

$L D H$ release assay. The $\mathrm{LDH}$ release assay was performed using the Pierce LDH Cytotoxicity Assay Kit from Thermo Scientific. Experiments were performed in replicates of five, and an additional 10 wells were used for controls. Cells were cultured in the inner 60 wells (rows B-G, columns 2-11) of the 96-well plate. DMEM:F12 media (100 $\mu \mathrm{L})$ was added to the outer wells (rows A and $\mathrm{H}$ and columns 1 and 12), in order to ensure the greatest reproducibility of data generated from the inner wells. A $10-\mathrm{mg} / \mathrm{mL}$ stock solution of UCI-1 was prepared gravimetrically in sterile deionized $\mathrm{H}_{2} \mathrm{O}$ that had been passed through a $0.2 \mu$ mylon syringe filter. The stock solution was used to create a $2560 \mu \mathrm{M}$ solution of UCI-1, which was serially diluted in sterile deionized $\mathrm{H}_{2} \mathrm{O}$ to create $10 \mathrm{X}$ working solutions of UCI-1.

HEK-293 cells were plated in a 96-well plate at 15,000 cells per well. Cells were incubated in $100 \mu \mathrm{L}$ of a 1:1 mixture of DMEM:F12 media supplemented with $10 \%$ fetal bovine 
serum, $100 \mathrm{U} / \mathrm{mL}$ penicillin, and $100 \mu \mathrm{g} / \mathrm{mL}$ streptomycin at $37{ }^{\circ} \mathrm{C}$ in a $5 \% \mathrm{CO}_{2}$ atmosphere and allowed to adhere to the bottom of the plate for 24 hours. After 24 hours, the culture media was removed and replaced with $90 \mu \mathrm{L}$ of serum-free DMEM:F12 media. A 10- $\mu \mathrm{L}$ aliquot of the working solutions of UCI-1 was added to each well, for well concentrations of $256 \mu \mathrm{M}$ to 32 $\mu \mathrm{M}$. Experiments were run in replicates of five. Five wells were used as controls and received $10-\mu \mathrm{L}$ aliquots of sterile deionized water (vehicle). Another five wells were left untreated, to be subsequently used as controls with lysis buffer for the LDH release assay. Cells were incubated at $37^{\circ} \mathrm{C}$ in a $5 \% \mathrm{CO}_{2}$ atmosphere for 72 hours.

After 72 hours, $10 \mu \mathrm{L}$ of $10 \mathrm{x}$ lysis buffer — included with the assay kit — was added to the five untreated wells, and the cells were incubated for an additional $45 \mathrm{~min}$. After $45 \mathrm{~min}$, a $50-\mu \mathrm{L}$ aliquot of the supernatant media from each well was transferred to a new 96-well plate and $50 \mu \mathrm{L}$ of LDH substrate solution, prepared according to manufacturer's protocol, was added to each well. The treated plates were stored in the dark for $30 \mathrm{~min}$. The absorbance of each well was measured at 490 and $680 \mathrm{~nm}\left(\mathrm{~A}_{490}\right.$ and $\left.\mathrm{A}_{680}\right)$. Data were processed by calculating the differential absorbance for each well $\left(\mathrm{A}_{490}-\mathrm{A}_{680}\right)$ and comparing those values to those of the lysis buffer controls and the untreated controls:

$$
\% \text { cell death }=\left[\left(\mathrm{A}_{490}-\mathrm{A}_{680}\right)_{\text {compound }}-\left(\mathrm{A}_{490}-\mathrm{A}_{680}\right)_{\text {vehicle }}\right] /\left[\left(\mathrm{A}_{490}-\mathrm{A}_{680}\right)_{\text {lysis }}-\left(\mathrm{A}_{490}-\mathrm{A}_{680}\right)_{\text {vehicle }}\right]
$$

Docking of UCI-1 to SARS-CoV-2 $M^{\text {pro }}$. The model of the SARS-CoV-2 $\mathrm{M}^{\text {pro }}$ was generated as follows: Starting coordinates of SARS-CoV-2 $\mathrm{M}^{\text {pro }}$ were generated from the SARSCoV-2 M $\mathrm{M}^{\text {pro }}$ crystallographic structure (PDB 6YB7) using PyMOL and saved as a new PDB file. In PyMOL the dimethyl sulfoxide molecule that sits in the active site of 6YB7 was deleted. iBabel was used to convert the UCI-1 minimized structured PDB file into a PDBQT file prior to docking. Docking was performed using AutoDock Tools and AutoDock Vina. In AutoDock 
Tools, a grid was chosen to encompass the active site of SARS-CoV-2 $\mathrm{M}^{\text {pro }}$ in the size of $25 \times 25 \times 25 \AA$ and with the coordinates $\mathrm{x}=9.250, \mathrm{y}=-5.944, \mathrm{z}=18.944 . \mathrm{SARS} C \mathrm{CV}-2 \mathrm{M}^{\mathrm{pro}}$ was treated as a rigid receptor in these calculations. The lowest energy cluster, as determined by AutoDock Vina was chosen to represent the SARS-CoV-2 $\mathrm{M}^{\text {pro }}$ UCI-1 interaction model in Figure 7C.

\section{AUTHOR CONTRIBUTIONS}

A.G.K. and J.S.N. conceived and designed UCI-1 and the research. A.G.K., M.K., and M.A.M. synthesized Fmoc-AEPA-OH. A.G.K., C.M.T.P., and M.A.M. synthesized UCI-1, peptide-1a, and peptide-1b. A.G.K. performed the enzyme inhibition assays and the LC/MS experiments. G.G. performed the LDH release assays. A.G.K. and J.S.N. performed the conformational analysis. M.K. performed the docking study. A.G.K. and J.S.N. wrote the manuscript. All authors read and approved the manuscript.

\section{AUTHOR INFORMATION}

\section{Corresponding Author}

James S. Nowick

jsnowick@uci.edu

\section{ORCID}

Adam G. Kreutzer: 0000-0002-9724-6298

Maj Krumberger: 0000-0003-2301-1784

Chelsea Marie T. Parrocha: 0000-0002-6502-1297

Michael A. Morris: 0000-0003-4526-271X 
Gretchen Guaglianone: 0000-0002-5189-2550

James S. Nowick: 0000-0002-2273-1029

Notes

The authors declare no competing financial interest.

\section{ACKNOWLEDGEMENTS}

\section{ADDITIONAL INFORMATION}

Supplementary information accompanies this paper. 


\section{REFERENCES AND NOTES}

1 Zhou P, Yang XL, Wang XG, Hu B, Zhang L, Zhang W, Si HR, Zhu Y, Li B, Huang CL, Chen HD, Chen J, Luo Y, Guo H, Jiang RD, Liu MQ, Chen Y, Shen XR, Wang X, Zheng XS, Zhao K, Chen QJ, Deng F, Liu LL, Yan B, Zhan FX, Wang YY, Xiao GF, Shi ZL. A pneumonia outbreak associated with a new coronavirus of probable bat origin. Nature. 2020 Mar;579(7798):270-273. doi: 10.1038/s41586-020-2012-7. Epub 2020 Feb 3. PMID: 32015507; PMCID: PMC7095418.

2 Wu F, Zhao S, Yu B, Chen YM, Wang W, Song ZG, Hu Y, Tao ZW, Tian JH, Pei YY, Yuan ML, Zhang YL, Dai FH, Liu Y, Wang QM, Zheng JJ, Xu L, Holmes EC, Zhang YZ. A new coronavirus associated with human respiratory disease in China. Nature. 2020 Mar;579(7798):265-269. doi: 10.1038/s41586-020-2008-3. Epub 2020 Feb 3. Erratum in: Nature. 2020 Apr;580(7803):E7. PMID: 32015508; PMCID: PMC7094943.

3 Beigel JH, Tomashek KM, Dodd LE, Mehta AK, Zingman BS, Kalil AC, Hohmann E, Chu HY, Luetkemeyer A, Kline S, Lopez de Castilla D, Finberg RW, Dierberg K, Tapson V, Hsieh L, Patterson TF, Paredes R, Sweeney DA, Short WR, Touloumi G, Lye DC, Ohmagari N, Oh MD, Ruiz-Palacios GM, Benfield T, Fätkenheuer G, Kortepeter MG, Atmar RL, Creech CB, Lundgren J, Babiker AG, Pett S, Neaton JD, Burgess TH, Bonnett T, Green M, Makowski M, Osinusi A, Nayak S, Lane HC; ACTT-1 Study Group Members. Remdesivir for the Treatment of Covid-19 - Preliminary Report. N Engl J Med. 2020 May 22. doi: 10.1056/NEJMoa2007764. Epub ahead of print. PMID: 32445440.

4 Anand K, Ziebuhr J, Wadhwani P, Mesters JR, Hilgenfeld R. Coronavirus main proteinase (3CLpro) structure: basis for design of anti-SARS drugs. Science. 2003 Jun 13;300(5626):1763-7. doi: 10.1126/science.1085658. Epub 2003 May 13. PMID: 12746549.

5 Hilgenfeld R. From SARS to MERS: crystallographic studies on coronaviral proteases enable antiviral drug design. FEBS J. 2014 Sep;281(18):4085-96. doi: 10.1111/febs.12936. Epub 2014 Aug 11. PMID: 25039866; PMCID: PMC7163996.

6 Zhang L, Lin D, Kusov Y, Nian Y, Ma Q, Wang J, von Brunn A, Leyssen P, Lanko K, Neyts J, de Wilde A, Snijder EJ, Liu H, Hilgenfeld R. $\alpha$-Ketoamides as Broad-Spectrum Inhibitors of Coronavirus and Enterovirus Replication: Structure-Based Design, Synthesis, and Activity Assessment. J Med Chem. 2020 May 14;63(9):4562-4578. doi: 10.1021/acs.jmedchem.9b01828. Epub 2020 Feb 24. PMID: 32045235; PMCID: PMC7098070.

7 Xue X, Yu H, Yang H, Xue F, Wu Z, Shen W, Li J, Zhou Z, Ding Y, Zhao Q, Zhang XC, Liao M, Bartlam M, Rao Z. Structures of two coronavirus main proteases: implications for substrate binding and antiviral drug design. J Virol. 2008 Mar;82(5):2515-27. doi: 10.1128/JVI.02114-07. Epub 2007 Dec 19. PMID: 18094151; PMCID: PMC2258912. 
8 Vuong W, Khan MB, Fischer C, Arutyunova E, Lamer T, Shields J, Saffran HA, McKay RT, van Belkum MJ, Joyce M, Young HS, Tyrrell DL, Vederas JC, Lemieux MC. Feline coronavirus drug inhibits the main protease of SARS-CoV-2 and blocks virus replication. bioRxiv 2020.05.03.073080; doi: 10.1101/2020.05.03.073080.

9 Douangamath A, Fearon D, Gehrtz P, Krojer T, Lukacik P, Owen CD, Resnick E, StrainDamerell C, Aimon A, Ábrányi-Balogh P, Brandaõ-Neto J, Carbery A, Davison G, Dias A, Downes TD, Dunnett L, Fairhead M, Firth JD, Jones SP, Keely A, Keserü GM, Klein HF, Martin MP, Noble MEM, O’Brien P, Powell A, Reddi R, Skyner R, Snee M, Waring MJ, Wild C, London N, von Delft F, Walsh MA. Crystallographic and electrophilic fragment screening of the SARS-CoV-2 main protease. bioRxiv 2020.05.27.118117 doi: 10.1101/2020.05.27.118117. PPR:PPR168175.

10 Dragovich PS, Prins TJ, Zhou R, Webber SE, Marakovits JT, Fuhrman SA, Patick AK, Matthews DA, Lee CA, Ford CE, Burke BJ, Rejto PA, Hendrickson TF, Tuntland T, Brown EL, Meador JW 3rd, Ferre RA, Harr JE, Kosa MB, Worland ST. Structure-based design, synthesis, and biological evaluation of irreversible human rhinovirus 3C protease inhibitors. 4. Incorporation of P1 lactam moieties as L-glutamine replacements. J Med Chem. 1999 Apr 8;42(7):1213-24. doi: 10.1021/jm9805384. PMID: 10197965.

11 Hegyi A, Ziebuhr J. Conservation of substrate specificities among coronavirus main proteases. J Gen Virol. 2002 Mar;83(Pt 3):595-599. doi: 10.1099/0022-1317-83-3-595. PMID: 11842254.

12 Zhang L, Lin D, Sun X, Curth U, Drosten C, Sauerhering L, Becker S, Rox K, Hilgenfeld R. Crystal structure of SARS-CoV-2 main protease provides a basis for design of improved $\alpha$ ketoamide inhibitors. Science. 2020 Apr 24;368(6489):409-412. doi: 10.1126/science.abb3405. Epub 2020 Mar 20. PMID: 32198291; PMCID: PMC7164518.

13 Jin Z, Du X, Xu Y, Deng Y, Liu M, Zhao Y, Zhang B, Li X, Zhang L, Peng C, Duan Y, Yu J, Wang L, Yang K, Liu F, Jiang R, Yang X, You T, Liu X, Yang X, Bai F, Liu H, Liu X, Guddat LW, Xu W, Xiao G, Qin C, Shi Z, Jiang H, Rao Z, Yang H. Structure of Mpro from SARS-CoV-2 and discovery of its inhibitors. Nature. 2020 Apr 9. doi: 10.1038/s41586-0202223-y. Epub ahead of print. PMID: 32272481.

14 Dai W, Zhang B, Su H, Li J, Zhao Y, Xie X, Jin Z, Liu F, Li C, Li Y, Bai F, Wang H, Cheng X, Cen X, Hu S, Yang X, Wang J, Liu X, Xiao G, Jiang H, Rao Z, Zhang LK, Xu Y, Yang $\mathrm{H}$, Liu H. Structure-based design of antiviral drug candidates targeting the SARS-CoV-2 main protease. Science. 2020 Apr 22:eabb4489. doi: 10.1126/science.abb4489. Epub ahead of print. PMID: 32321856; PMCID: PMC7179937.

15 Cohen MS, Corey L. Combination Prevention for COVID-19. Science. 2020 May 08;368(6491):550. doi: 10.1126/science.abc5798. 
16 Muramatsu T, Takemoto C, Kim YT, Wang H, Nishii W, Terada T, Shirouzu M, Yokoyama S. SARS-CoV 3CL protease cleaves its C-terminal autoprocessing site by novel subsite cooperativity. Proc Natl Acad Sci U S A. 2016 Nov 15;113(46):12997-13002. doi: 10.1073/pnas.1601327113. Epub 2016 Oct 31. PMID: 27799534; PMCID: PMC5135343.

17 Schlippe YV, Hartman MC, Josephson K, Szostak JW. In vitro selection of highly modified cyclic peptides that act as tight binding inhibitors. J Am Chem Soc. 2012 Jun 27;134(25):10469-77. doi: 10.1021/ja301017y. Epub 2012 Mar 29. PMID: 22428867; PMCID: PMC3384292.

18 Vinogradov AA, Yin Y, Suga H. Macrocyclic Peptides as Drug Candidates: Recent Progress and Remaining Challenges. J Am Chem Soc. 2019 Mar 13;141(10):4167-4181. doi: 10.1021/jacs.8b13178. Epub 2019 Feb 27. PMID: 30768253.

19 Gang D, Kim DW, Park HS. Cyclic Peptides: Promising Scaffolds for Biopharmaceuticals. Genes (Basel). 2018 Nov 16;9(11):557. doi: 10.3390/genes9110557. PMID: 30453533; PMCID: PMC6267108.

20 Sawyer T. CHAPTER 1:Renaissance in Peptide Drug Discovery: The Third Wave, in Peptide-based Drug Discovery: Challenges and New Therapeutics. 2017 pp. 1-34 doi: 10.1039/9781788011532-00001

21 Morrison C. Constrained peptides' time to shine? Nat Rev Drug Discov. 2018 Jul 30;17(8):531-533. doi: 10.1038/nrd.2018.125. PMID: 30057410.

22 Dougherty PG, Sahni A, Pei D. Understanding Cell Penetration of Cyclic Peptides. Chem Rev. 2019 Sep 11;119(17):10241-10287. doi: 10.1021/acs.chemrev.9b00008. Epub 2019 May 14. PMID: 31083977; PMCID: PMC6739158.

23 Trott O, Olson AJ. AutoDock Vina: improving the speed and accuracy of docking with a new scoring function, efficient optimization, and multithreading. J Comput Chem. 2010 Jan 30;31(2):455-61. doi: 10.1002/jcc.21334. PMID: 19499576; PMCID: PMC3041641.

24 Bollhagen, R.; Schmiedberger, M.; Barlosb, K.; Grell, E. A new reagent for the cleavage of fully protected peptides synthesised on 2-chlorotrityl chloride resin. J. Chem. Soc., Chem. Commun. 1994, 2559-2560. 